\title{
Mimic Pollination in Ornamental Plants
}

\author{
A. Sankari*, P. Loganayki and M. Anand
}

${ }^{1} H C \& R I, T N A U$, India

\author{
${ }^{2}$ Depatment of Floriculture and Landscaping, TNAU, India \\ ${ }^{3}$ HRS, Yercaud, India \\ *Corresponding author
}

\section{A B S T R A C T}

\section{Keywords}

Mimic pollination, Ornamental plants, Butterfly, Bird

Article Info

Accepted:

20 March 2019

Available Online:

10 April 2019
Pollination is the act of transferring pollen grains from the male anther of a flower to the female stigma. Mimicry in plants is where a plant organism evolves to resemble another organism physically or chemically, increasing the mimic's Darwinian fitness. Mimicry in plants has been studied far less than mimicry in animals, with fewer documented cases and peer-reviewed studies. It may provide protection against herbivory, or may deceptively encourage mutualists, like pollinators, to provide a service without offering a reward in return. Pollination is a very important part of the life cycle of plants. Insects, birds, bats and the wind take pollen between flowering plants, which means the plants can make seeds and reproduce. Its significance is to carry the pollen grains to the stigma for the process of fertilisation.

\section{Introduction}

\section{Mimicry in plants}

Mimicry in plants is where a plant organism evolves to resemble another organism physically or chemically, increasing the mimic's Darwinian fitness. Mimicry in plants has been studied far less than mimicry in animals, with fewer documented cases and peer-reviewed studies. It may provide protection against herbivory, or may deceptively encourage mutualists, like pollinators, to provide a service without offering a reward in return $(1,2,3)$.

\section{Advantages of mimicry plants}

It attracts the pollinators

Escape the predation from herbivores

It maintains the diversity 
Mimic plants will maintain the descendents characters

Pseudocopulation increase pollination capacity

Mimic in plants is a vivid demonstration of natural selection as a guiding force in evolutionary change (4-6).

Uses of mimicry

\section{Mutualism}

\section{Friendly mutualism}

Here help each other, both benefit and no one is harmed. No free lunch, but benefits higher than costs.

\section{Antagonism}

One benefits, another is harmed.

\section{Commensalism}

One benefits, another is unaffected.

Pollination systems

1. Attracting pollinators: visual cues

\begin{tabular}{|l|l|}
\hline $\begin{array}{l}\text { A “Bull's eye" color } \\
\text { pattern(background } \\
\text { of green foliage) }\end{array}$ & $\begin{array}{l}\text { Rudbeckia, a } \\
\text { black-eyed susan }\end{array}$ \\
\hline $\begin{array}{l}\text { A reversed bull's } \\
\text { eye }\end{array}$ & $\begin{array}{l}\text { day } \\
\text { Hemerocallis }\end{array}$ \\
\hline Human \& butterfly & $\begin{array}{l}\text { Gaillardia, } \\
\text { painted daisy }\end{array}$ \\
\hline Honey bee & $\begin{array}{l}\text { orange/white } \\
\text { flowers }\end{array}$ \\
\hline
\end{tabular}

\section{Attracting pollinators: olfactory cues}

\begin{tabular}{|c|c|}
\hline $\begin{array}{l}\text { Butterfly, } \\
\text { Bird }\end{array}$ & $\begin{array}{l}\text { more visual in } \\
\text { behaviour and not } \\
\text { very olfactory }\end{array}$ \\
\hline Bees & sweet or spicy \\
\hline Moth & $\begin{array}{l}\text { very heady sweet } \\
\text { fragrances }\end{array}$ \\
\hline Bats & $\begin{array}{l}\text { Strong fruity or } \\
\text { musky scents }\end{array}$ \\
\hline
\end{tabular}

\section{Attracting pollinators: shape}

\begin{tabular}{|l|l|}
\hline Beetle & $\begin{array}{l}\text { easy, open entrance, } \\
\text { structural foods }\end{array}$ \\
\hline $\begin{array}{l}\text { Hovering } \\
\text { pollinators }\end{array}$ & $\begin{array}{l}\text { generally hang down } \\
\text { and have a long nectar } \\
\text { tube }\end{array}$ \\
\hline $\begin{array}{l}\text { Non-hovering } \\
\text { insects and birds }\end{array}$ & $\begin{array}{l}\text { need perches or landing } \\
\text { platforms as part of the } \\
\text { flower }\end{array}$ \\
\hline $\begin{array}{l}\text { Mimicry of } \\
\text { female }\end{array}$ & Drakea spp. \\
\hline
\end{tabular}

Pollination syndrome

\begin{tabular}{|l|l|l|}
\hline Cantharophily & $\begin{array}{l}\text { Beetle } \\
\text { pollination }\end{array}$ & I. atropurpurea \\
\hline Myophily & $\begin{array}{l}\text { Fly } \\
\text { pollination }\end{array}$ & $\begin{array}{l}\text { Skunk cabbage } \\
\text { lady-slipper orchid } \\
\text { (Cypripedium } \\
\text { spp)Alcohol produce }\end{array}$ \\
\hline Phalaenophily & $\begin{array}{l}\text { Moth } \\
\text { pollination }\end{array}$ & $\begin{array}{l}\text { Gymnadenia } \\
\text { conopsea Fragrant } \\
\text { Orchid) Pollinated } \\
\text { by Hummingbird } \\
\text { Hawkmoth }\end{array}$ \\
\hline Psychophily & $\begin{array}{l}\text { Butter } \\
\text { pollination }\end{array}$ & $\begin{array}{l}\text { Gaillardia(painted } \\
\text { daisy) }\end{array}$ \\
\hline Melittophily & $\begin{array}{l}\text { Bees } \\
\text { pollination }\end{array}$ & $\begin{array}{l}\text { Morning } \\
\text { Mectan sunflower } \\
\text { figs-fig wasps } \\
\text { yuccas-yucca moths } \\
\text { (Tegeticula) }\end{array}$ \\
\hline pbligate & &
\end{tabular}




\section{Herbivory}

\section{Venus's fly trap}

The two-lobbed trap: 3 trigger hairs on the inner face of each lobe, fringed with teeth-like projections. When one trigger hair is touched twice or when two are touched in succession, the trap closes. The teeth-like projections interlock, trapping the unsuspecting victim inside. The struggling victim stimulates the secretion of digestive juices. The trap reopens in about 10 days (7).

\section{Sundew}

More than 100 species of sundews (Drosera). Leaves are covered with tiny (usually red) hairs, which exude a clear, sticky fluid (dewdrops).The sticky droplets attract and trap insects. The struggling insect stimulates the hairs to bend inward towards the centre of the leaf, to wrap it in a neat, tight package.

\section{Butterwort}

Leaves with a very sticky surface. Greasy to the touch, but deadly to any small insect that may land on or try to cross one of the leaves.

\section{Pitcher plants}

Leaves or leave parts modified into pitcherlike structures. Pitchers contain plant juice that smells like sweet nectar and attracts insects. Pitchers are topped with a hood or lid. When insect try to drink from the pitcher, it loses its footing on the smooth interior, slides to the bottom, lands in a pool of liquid, which digests the victim.

\section{Types of mimicry in plants}

1. Bakerian

2. Dodsonian

3. Vavilovian

4. Pouyannian

\section{Batesian}

6. Cryptic

\section{Bakerian}

Bakerian mimicry, named after English naturalist Herbet Baker, is a form of automimicry or intraspecific mimicry that occurs within a single species. In plants, the female flowers, mimic male flowers of their own species, cheating pollinators out of a reward. This reproductive mimicry may not be readily apparent as members of the same species may still exhibit some degree of sexual dimorphism, i.e. the phenotypic difference between males and females of the same species.

\section{Examples}

It is common in many species of Caricaceae, a family of flowering plants in the family of Brassicaceae, found primarily in tropical regions of Central and South America, and Africa.

\section{Dodsonian}

Dodsonian mimicry, named after American botanist, orchidologist, and taxonomist, Calaway H. Dodson, is a form of reproductive floral mimicry, but the model belongs to a different species than the mimic. By providing similar sensory signals as the model flower, it can lure its pollinators. Like Bakerian mimics, no nectar is provided.

\section{Examples}

\begin{tabular}{|l|l|l|l|}
\hline S.No & Crop & $\begin{array}{l}\text { Resemble } \\
\text { crop }\end{array}$ & Pollinators \\
\hline 1. & $\begin{array}{l}\text { Epidendrum } \\
\text { ibaguense }\end{array}$ & $\begin{array}{l}\text { Lantana } \\
\text { camara and } \\
\text { Asclepias } \\
\text { curassavica }\end{array}$ & $\begin{array}{l}\text { Humming } \\
\text { birds and } \\
\text { Monarch } \\
\text { butterfly }\end{array}$ \\
\hline 2. & Cistus spp. & Ophrys spp. & $\begin{array}{l}\text { Lamellicorn } \\
\text { beetle }\end{array}$ \\
\hline
\end{tabular}


Epidendrum ibaguense a species of epiphytic orchid of the genus. Epidendrum that occurs in Trinidad, French, Venezuela, Colombia, and Northern Brazil, resembles flowers of Lantana camera and Asclepias curassavica (commonly called Mexican butterfly weed, blood-flower, scarlet milkweed, or tropical milkweed), both are species of flowering plant with the first in the Verbena family, while the latter belongs to the milkweed family, and both are native to the American tropics. Epidendrum ibaguense is pollinated by Monarch butterfly (Danaus plexippus) and perhaps humming birds. Similar cases are seen in some other species of the same family.

The mimetic species may still have pollinators of its own though, for example a Lamellicorn beetle, which usually pollinates correspondingly coloured Cistus spp. flowers, is also known to aid in pollination of Ophrys spp. that are normally pollinated by bees (8).

\section{Vavilovian}

Vavilovian mimicry named after Russian plant geneticist who identified the centres of origin of cultivated plants, Nikolai Vavilov is a form of mimicry in plants where a weed comes to share one or more characteristics with a domesticated through generations of artificial selection. It is also known as crop mimicry or weed mimicry. Selection against the weed may occur by killing a young or adult weed, separating its seeds from those of the crop (winnowing), or both. This has been done manually since Neolithic times, and in more recent years by agricultural machinery.

\section{Examples}

Erigeron Canadensis (weed species) have same similar character inflorence a cultivated species of Amaranthus palmeri

Annual bluegrass is mowing tolerance capacity and used as Gulf course in foreign countries. It is suitable for temperate region. Creeping bent grass also express the same characters of Annual blue grass which is normally used as gulf course in now-a-days.

\section{Pouyannian}

Many plants have evolved to appear like other organisms, most commonly insects. This can have wide-ranging benefits including increasing pollination. The flowers mimic a potential female mate visually, but the key stimuli are often chemical and tactile.

\section{Examples}

The hammer orchid (Drakaea spp.) an endangered genus of orchid that is native to Australia is one of the most notable examples. The orchid has both visual and olfactory mimics of a female wasp to lure males to both deposit and pick up pollen.

The orchid Epipactis helleborine is physiologically and morphologically adapted to attract social wasps as their primary pollinators. Social wasps feed their larvae on insects like caterpillars. To locate that prey, they use a combination of visual and olfactory cues. The flowers of E.helleborine and $E$. purpurata emit green-leaf volatiles (GLVs), which are attractive to foragers of the social wasps Vespula germanica and V.vulgaris. Several E. helleborine GLVs that induced a response in the antennae of wasps were also emitted by cabbage leaves infested with caterpillars (Pieris brassicae), which are common prey items for wasps. Despite a large nectar reward, the species is almost entirely overlooked by other pollinators.

Carrion flowers mimic the scent and appearance of rotting flesh to attract necrophagous (carrion-feeding) insects like flesh flies (Sarcophagidae), blowflies (Calliphoridae), house flies (Muscidae) and some beetles (e.g., Dermestidae and 
Silphidae) which search for dead animals to use as brood sites. The decaying smell of the flower comes from oligosulfides, decayed proteins that contain amino acids methionine and cysteine. While carrion flowers do produce a small amount of nectar, this does not necessarily make its relationship to necrophagous insects mutualistic. Insects lay eggs on the carrion flowers, meaning they mistake them for oviposition sites. The nectar acts as a lure to bring the insects closer to the reproductive parts of the flower.

\section{Batesian}

Batesian mimicry is a form of mimicry, named after the English naturalist Henry Walter Bates, where a harmless species has evolved to imitate the warning signals of a harmful species directed at a predator.

\section{Examples}

Thorn mimicry of two types has been observed in plants. The first, a special case of intra-oranismic Batesian mimicry characteristic of Aloe spp. (Liliaceae), $W$. filifera (Palmaceae), and dozens of species of Agave, including A. applanta, A. salmiana, and A. obscura. These plants develop thornlike imprints or colorations on the face of their leaves due to the teeth along the margins of that leaf (or another leaf) pressing sustained indentations into the flesh of the non-spiny parts.

The second type of thorn mimicry, a more classic case of Batesian mimicry, involves the pointed, colourful organs like buds, leaves and fruit of mimitic plant species that mimic aposematic colourful thorns not found anywhere else organism.

Several plants growing in Israel, Estonia, Greece, and Japan exhibit possible spider web mimicry. Dense, white trichomes spp. are produced on newly extended stems and leaves that deter herbivory due to predatory habit or toxicity. This may be a case of visual mimicry or perceptual exploitation. Case examples include the new buds of Onopordum spp. from Israel, Carthamus sp. from Greece, flower heads of Articum tomentosum from Estonia, a fledgling leaf of Tussilago farfara from Estonia, and new fronds of Osmunda japonica from Japan.

\section{Difficult example for bucket orchid Pollination}

The bucket orchid of Central America, is equipped with a small bucket structure behind the flower. The flower produces oil which drips into the "bucket" and attracts bees with its unique odour. Each bucket orchid species has its own scent, thus each attracts its own species of bee. When the male bees smells the perfume, it goes to the orchid to collect an oily substance which he will use to attract females (he is only attracted to one orchid species scent since he wants to attract only female species). However, often as he is collecting his oil, the bee falls into the bucket. The only way out is through a tube. The bees moves through a tube, getting "tagged" with orchid pollen, so when he visits the next flower he will pollinate it as he passes through its funnel (9-12).

\section{Cryptic mimicry}

In ecology, crypsis is an organism's ability to avoid detection by other organisms. Therefore, cryptic mimicry is a situation where a prey organism deceives a potential predator by providing false signals or a lack of signals. Cryptic mimicry in plants is usually achieved visually.

\section{Example}

The South American Boquila trifoliata, of the Lardizabalaceae family, is a climbing vine with a highly variable phenotype. It is capable 
of mimicking the leaf features of plant species that it clings to, adopting colour shape and size. By camouflaging its leafy appendages, Boquila lowers its rate of herbivory.

\section{References}

1. Disa pulchra, and its consequences for pollinator behaviour, Biological 3oumal ufthe Linnean S o c i e (2000), 71: 119132.

2. Ernesto Gianoli, and Fernando CarrascoUrra, (2014), Leaf Mimicry in a Climbing Plant

3. Gumbefu, A. and Kunze, J. (2001), Colour similarity to rewarding model plants affects pollination in a food deceptive orchid, Orchis boryi, Biological Journal of the Linnean Society (2001), 72: 419-433.

4. https://en.wikipedia.org/wiki/Batesian_m imicry.

5. Johnson, S. D. (1999), Batesian mimicry in the non-rewarding orchid

6. Nicolas J. Vereecken et al., (2013), A pollinators' eye view of a shelter mimicry system, Annals of Botany 111: 11551165, 2013.

7. Paulette Bierzychudek, (2013),
Asclepias, Lantana, and Epidendrum: A Floral Mimicry Complex? Biotropica, Vol. 13, No. 2, Supplement: Reproductive Botany (Jun., 1981), pp. 54-58.

8. Protects against Herbivory, Current Biology (2014), http://dx.doi.org/10. 1016/j.cub.2014.03.010

9. Rod Peakall et al., (2010), Pollinator specificity, floral odour chemistry and the phylogeny of Australian sexually deceptive Chiloglottis orchids: implications for pollinator-driven speciation, New Phytologist (2010) 188: 437-450.

10. Scott McElroy J, (2014), Vavilovian Mimicry: Nikolai Vavilov and His LittleKnown Impact on Weed Science, Weed Science, 62(2):207-216. 2014.

11. Spencer C.H. Barret, (1987), Mimicry in plants, Scientific American (Sep 1987) VOL 255 NO.9.

12. Stephen D. Hopper A, C and Andrew P. Brown A revision of Australia s hammer orchids (Drakaea: Orchidaceae), with some field data on species-specific sexually deceived wasp pollinators, Australian Systematic Botany 20, 252285.

\section{How to cite this article:}

Sankari, A., P. Loganayki and Anand, M. 2019. Mimic Pollination in Ornamental Plants. Int.J.Curr.Microbiol.App.Sci. 8(04): 2969-2974. doi: https://doi.org/10.20546/ijcmas.2019.804.343 